\title{
浅析如何将德育融入到小学数学课堂教学中
}

张佃利张金磊

山东省临沂市临沭县郑山街道中心小学

DOI:10.32629/jief.v2i10.2250

[摘 要] 新的课程标准把德育教育放在十分重要的地位。小学教学大纲明确规定: 对学生进行思想品德教育, 帮助学生树立正确的人生观、 价值观，激发爱祖国、爱社会主义、爱科学的热情，培养良好的学习和生活习惯。这是数学教学目的的任务之一。所以数学教师的主要任务 除了传授数学知识，培养逻辑思维能力和运算能力以外，同时也要结合数学教学对学生进行有效的思想品德教育。

[关键词] 小学数学; 课堂教学; 德育渗透

中图分类号: G623 文献标识码: A

数学虽然是一门注重逻辑的学科, 但它本身蕴含大量的德育内容。 在小学阶段数学教学中, 教师应结合课程内容和学生年龄层挖掘德育素 材, 在课堂上进行德育渗透, 培养学生正确的人生观、价值观。那么如 何才能在小学数学教学中更好地渗透德育教育呢? 下面是我在教学中的 几点做法。

\section{1 联系实际进行学习目的教育}

数学知识在日常生活、生产建设和科技等方面有着广泛的应用。教 学时应根据学生的年龄特征和接受能力, 联系实际, 阐明所学知识的用 处, 从而不断激发学生的兴趣, 调动他们学习的主动性和积极性, 深入 浅出地进行学习目的教育。例如: 一年级教学 “元、角、分的认识”, 可 以介绍人民币在日常生活中的使用和生产建设中的作用; 二年级教学“万 以内的加法和减法” 时, 要使学生知道已学过的 “100 以内的加法和减 法” 不能满足人们在工作和生活中的需要, 这部分知识在今后的学习以 及人们在工作和生活中要经常用到; 三年级教学 “三步计算式题” 时, 可以介绍 “小括号” 在实际中的应用和在运算顺序中的作用; 四年级教 学 “三角形、平行四边形” 时, 可以介绍三角形、平行四边形的特征在 日常生活和生产建设中的应用; 五年级教学 “比例尺” 时, 可以介绍按 “比例尺”计算 “图上距离” 或 “实际距离”, 以及按 “比例尺” 绘制图 纸, 在建筑、科研、军事等方面的重要作用等等。通过教师简明扼要的 介绍, 要使学生把所学新知识同现实生活、今后的学习和国家的建设逐 步联系起来, 明确所学知识的重要性。

\section{2 结合教学内容进行爱祖国、爱社会主义、爱科学的教育}

数学教材中有很多插图和应用题, 教学时可以选择富有教育意义、 形象生动的插图, 有说服力的数据和统计材料, 以及数学史料等内容, 进行爱祖国、爱社会主义、爱科学的教育。例如: 一年级教学 “准备课”、 “ 5 的认识”、“ 10 的认识” 时, 教师可利用插图为媒体, 将画面编成数学 小故事, 通过对画面的处理, 使它由静变动, 由无声变有声, 对学生进 行爱学校、爱解放军、全国各族人民大团结的教育。中年级教学 “读数、 写数” 时, 可以有选择地介绍一些本地有教育意义的数据, 还可以介绍 我国的地形概况, 如我国地域广大, 东西相距约 5000 千米, 南北相距约 5500 千米, 领土面积约 960 万平方千米, 我国境内有世界著名的大河长 江, 长 6300 千米等。中、高年级教学 “应用题” 时, 可以根据应用题中 所反映的日常生活、工业、农业、卫生、交通、教育、科技等方面有说 服力的数据, 经过比较、分析, 进行爱家乡、爱祖国、爱社会主义、爱 科学的教育。高年级教学 “百分数” 时, 可以介绍中国人民用占世界耕 地面积 5\%的土地, 养活了世界上 $20 \%$ 的人口, 而且国家安定, 人民生活 幸福, 从而进行国情教育。另外, 还可以结合教学内容介绍一些我国的 发明创造, 如 “九九口诀” 和 “七巧板” 的发明, “珠算” 的历史, 以及 我国历史上祖冲之的辉煌成就等等。从而增强学生的民族自豪感和自信 心，树立长大后为祖国社会主义建设作贡献的雄心壮志。

\section{3 联系教材进行辩证唯物主义观点的启蒙教育}

数学教材中各部分知识之间存在着纵向和横向的紧密联系, 这些都 充满着唯物主义思想和辩证法, 教学时要充分利用这一特点, 进行辩证 唯物主义观点的启蒙教育。例如: 从低年级到高年级在知识的纵向发展 方面, 可以通过数学知识的产生, 揭示数学知识与现实生产、生活的关 系, 知道知识来源于实践, 服务于实际, 渗透一些 “实践第一” 的观点。 在知识的横向联系方面, 可以围绕数学概念之间的联系, 通过 “大与孝 多与少、加与减、乘与除、积与商的变化、正比例与反比例” 等内容, 渗透一些对立统一运动变化的观点。

小学生往往根据已有经验去思考问题，容易被许多司空见惯的虚假 现象迷惑, 产生思维定势。思维定势会帮助他们解决一些数学的问题, 如学生学习百分数应用题时, 可以应用学过的分数应用题的解法去类推, 学生就轻而易举地掌握了百分数应用题的解答方法。但有时也会将他们 引入误区而不能自拔。我们应该善于引导学生用辩证思考方法, 透过现 象, 抓住本质, 消除定势, 让学生用发展的、全面的、变化的观点去思 考问题。

\section{4 示范导行进行良好学习习惯的教育}

数学课上, 教师和学生的示范作用以及老师对学生的严格要求, 是 培养学生良好学习习惯的主要方法。教师的示范作用体现在, 教师要通 过自己的一言一行、一举一动来感染学生, 以自己严谨的教学风格和一 丝不苟的工作态度来影响学生。例如: 上课时, 教师着装要朴素大方, 讲普通话, 语言要清楚、明白、有逻辑性。板书要整齐, 书写要规范, 辅导 “后进生” 要耐心、细致, 使学生在教师的表率作用下, 潜移默化 地受到有益的熏陶和教育。学生的示范作用体现在, 课上教师要注意发 现有突出表现的学生, 用实例来激励其他同学。例如: 对上课认真听讲, 学习认真刻苦, 作业正确、整洁, 思考问题机智灵活等方面的同学, 教 师要及时表扬, 为其他同学树立学习的榜样。教学时, 教师还要针对所 教班级学生的特点提出不同程度的要求。

总之, 只要我们善于发现、善于分析、善于探索, 就不难找到在数 学课堂教学中进行德育渗透的思路和方法, 真正把德育落到实处, 提高 学校德育工作的实效性, 推动学校各项工作向前发展。

\section{[参考文献]}

[1]计奕倩.小学语文综合实践活动课程的实践研究 [J].散文百家(新 语文活页),2020(08):120.

[2]朱琳.论小学综合实践活动与家庭教育的融合[J].当代家庭教 育,2020(22):23.

[3]王中琨.刍议农村小学数学综合实践活动教学策略 [J]. 新课 程,2020(29):84. 